\title{
Brand experience and brand attachment as drivers of WOM in hospitality
}

\section{Experiencia de marca y vinculación afectiva como antecedentes de las recomendaciones boca-oído (WOM)}

\author{
Mónica Gómez-Suárez and Mónica Veloso
}

Departamento de Financiación e Investigación Comercial, Facultad de Ciencias Empresariales Avda. Tomas y Valiente s/n, Universidad Autónoma de Madrid, Madrid, Spain

\begin{abstract}
Purpose - The purpose of this paper is to develop a model to measure the impact of brand experience in the hotel industry, on word-of-mouth (WOM) recommendations while accounting for the possible mediating role of people's emotional attachment with the brand.
\end{abstract}

Design/methodology/approach - Data were collected through an online survey of 416 hotel customers. The proposed model was tested with structural equations modelling (SEM).

Findings - The results suggest that brand experience in the hotel sector is a consequence of four dimensions: location, ambience, staff and Web, in that order of influence. In addition, the study confirms the mediating role of emotional attachment in the relationship between experience and WOM recommendations. However, the experience itself has a greater direct impact than the attachment.

Practical implications - By knowing the dimensions that comprise the hotel brand experience, managers can design more impactful experiences that create strong links with guests, thereby increasing WOM recommendations.

Originality/value - This paper enriches the existing literature on brand experience in the hospitality sector and provides evidence of the mediating role of emotional bonding. Previous research has proven that linking is a consequence of experience, but not yet examined its mediating role.

Keywords Hotel, WOM, Brand experience, Brand attachment

Paper type Research paper

(C) Mónica Gómez-Suárez and Mónica Veloso. Published in Spanish Journal of Marketing - ESIC. Published by Emerald Publishing Limited. This article is published under the Creative Commons Attribution (CC BY 4.0) licence. Anyone may reproduce, distribute, translate and create derivative works of this article (for both commercial and non-commercial purposes), subject to full attribution to the original publication and authors. The full terms of this licence may be seen at http:// creativecommons.org/licences/by/4.0/legalcode

Brand

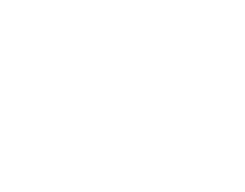




\section{Resumen}

Propósito - El objetivo principal de esta investigación es desarrollar un modelo para medir el impacto de la experiencia de marca en la industria hotelera, sobre las recomendaciones boca-oído, teniendo en cuenta el posible rol mediador de la vinculación afectiva con la marca.

Diseño/metodología/enfoque - Los datos se recogieron mediante una encuesta online a 416 clientes de hoteles. La contrastación del modelo propuesto se ha realizado mediante el desarrollo de un modelo con ecuaciones estructurales (SEM).

Hallazgos - Los resultados sugieren que la experiencia de marca en el sector hotelero, es consecuencia de cuatro dimensiones (ubicación, ambiente, personal y web), siendo ubicación, ambiente y personal más influyentes que la web en la generación de experiencias. Se confirma el rol mediador de la vinculación afectiva en la relación entre la experiencia y las recomendaciones boca-oído. No obstante, la experiencia tiene mayor impacto directo que el vínculo afectivo en esta relación.

Implicaciones prácticas - Conocer las dimensiones que integran la experiencia de marca en el hotel, permite a los gerentes diseñar mejores experiencias que impacten a sus huéspedes y consigan y crear fuertes vínculos con ellos, incrementando así las recomendaciones boca-oído.

Originalidad/valor - El presente trabajo enriquece la literatura existente sobre experiencia de marca en el sector turístico y aporta evidencias del rol mediador de la vinculación afectiva. Investigaciones previas han probado que la vinculación es consecuencia de la experiencia, pero no su papel mediador.

Palabras clave Experiencia de marca, Vinculación afectiva, Recomendaciones boca-oído, Hotel

Tipo de artículo Artículo de investigación

\section{Introduction}

Brand experience is a relatively new concept in marketing. Concerning the generation of unique, pleasant and memorable experiences, this notion has begun capturing the attention of both academics and practitioners (Jain et al., 2017). According to Pine and Gilmore (1998, 2002b), two pioneers in research on the "experience economy," the evolution of the commodity economy has increased the economic value of experiences, up to a fourth stage called experience economics, in what is known as the progression of economic value. This transition has forced service businesses to differentiate themselves from the competition. Hotels are a useful microcosm of this shift and thus constitute our core focus in this paper.

The hotel is a fundamental element in the tourism sector, often providing a hub for the experiences that promote tourists' psychological well-being (García et al., 2018). In this regard, it is important to note that, while people generally evaluate experiences on both a cognitive and emotional level, this process is predominantly emotional in the tourism sector (Serra-Cantallops et al., 2018) because tourists are basically traveling for pleasure. Consequently, hotel brands are important for adding value to both customers and the hotel itself. Therefore, academics and professionals agree that hotels need to generate unique, emotional and unforgettable experiences that facilitate desirable consumer behaviors (Kang, 2015; Khan and Rahman, 2015; Sukhu et al., 2018). The positive emotions and memories from the experience (Serra-Cantallops et al., 2018) then contribute to emotional bonds between consumers and brands (Huang, 2017).

As the concept of brand experience has gained traction, the literature has underscored several developmental issues. The first problem is the indiscriminate use of the theoretical perspective from the studies of Schmitt (1999) and Brakus et al. (2009). Most authors apply them without providing any additional criticism or theoretical elaboration (Andreini et al., 2018). In this research, we have tried to provide a critical vision by using a scale and dimensions that, in our opinion, more realistically represents the brand experience in the hotel sector.

Second, the marketing literature has hardly examined the mechanisms that mediate the relationship between brand experience and its possible consequences (Huang, 2017). 
Scholars have yet to perform an in-depth analysis of the mediating role of emotions in the relationship between experience design and customer evaluation (Pullman and Gross, 2004). Only recently have some authors, such as Huang (2017), Aro et al. (2018) and Ramirez and Merunka (2019), begun to consider the mediating role of other variables, such as brand love, trust or brand credibility, in the relationship between brand experience and its consequences. Authors such as Delgado Ballester and Fernández (2011) have verified the effects of experience in word-of-mouth (WOM) communications, while others have shown that previous experience in the tourism field shapes tourists' evaluations (Beerli and Martín, 2004; Del Barrio García et al., 2012). However, we are not aware of any cases establishing the mediating effect of brand attachment in the hotel environment. We will seek to confirm this relationship in the Spanish hotel context.

In short, this article contributes to the literature on brand experience in the tourism-hotel sector. Our objectives are twofold: first, we aim to show that the brand experience in the hotel sector has a positive and direct effect on WOM recommendations. Second, we examine the relationship between experience and WOM recommendations through the mediation of brand attachment - a relationship that has yet to be tested in the literature. To these ends, we developed a model that measures the impact of hotel brand experience on WOM recommendations while accounting for the possible mediating role of brand attachment.

\section{Theoretical framework}

\subsection{Brand experience}

Although Brakus et al. (2009) coined the term brand experience, Pine and Gilmore (1998, $2002 \mathrm{~b})$ stressed the importance of differentiating oneself from the competition, as well as attracting and retaining customers through experience. Therefore, they urged firms to abandon the service mentality, which is based on customer acquisition, and adopt an experience mentality that encourages consumers to spend more time in the hotel.

Brakus et al. (2009, p. 53) conceptualized brand experience as "sensations, feelings, cognitions and behavioral responses evoked by brand-related stimuli that are part of a brand's design and identity, packaging, communications, and environments." Experience should be understood as the subjective and internal responses of each consumer toward brand-related stimuli at each point of interaction. This contact can occur directly or indirectly (Ramirez and Merunka, 2019) during the purchase process, as the experience occurs at the moment in which "consumers search for products, when they shop for them and receive service, and when they consume them" (Brakus et al., 2009, p. 52).

According to Brakus et al. (2009), brand experience consists of four dimensions:

(1) Sensory: This includes the sensory stimulations provided by the brand. The visual aspects are more relevant, as they are easy to remember and help to configure the eesthetic sense of the environment (Beckman et al., 2013; Ramirez and Merunka, 2019).

(2) Affective: This includes emotions that may be mild (mood; consumers are not fully aware of the stimulus generated by such emotion) or intense (feelings; the stimulus is usually identified) (Schmitt, 1999; Beckman et al., 2013; Ramirez and Merunka, 2019).

(3) Intellectual: This is formed by analytical and imaginative thoughts, which stimulate people's curiosity and make them reflect (Schmitt, 1999; Beckman et al., 2013; Ramirez and Merunka, 2019).

(4) Behavioral: This includes physical actions caused by exposure to brand stimuli (Beckman et al., 2013; Ramirez and Merunka, 2019). 
Although this scale by Brakus et al. (2009) measures experience with a wide variety of product- and service-related brands, it features a small variety of hotel brands, which has led some authors (Walls, 2013; Khan and Rahman, 2017; Andreini et al., 2018) to question the scale's ability to measure experience in sectors such as hotels. For that reason, Khan and Rahman (2017, p. 281) defined the hotel brand experience as:

[...] a set of feelings, sensations, thoughts and behavioral responses toward hotel brand-related stimuli that are integral to the hotel brand's location, ambience, staff competence, website and social media presence and guest-to-guest interaction.

On this basis, they developed a new, validated scale that could capture these specificities within the framework established by Brakus et al. (2009).

Both sets of authors agree that experience is a subjective response caused by external stimuli. While Brakus et al. (2009) focused on the general level, Khan and Rahman (2017) tried to identify the specific and controllable stimuli that have an impact on consumers. The key to creating these memorable experiences is not to improve the functionality of the service, but to offer pleasant experiences by leveraging existing resources and services (Gilmore and Pine, 2002a). After a series of studies, Khan and Rahman (2017) identified these variables related to the hotel brand:

- Hotel location: The degree to which the location of the hotel brand fascinates to an individual's senses.

- Hotel stay and ambience: The extent to which a guest feels that the stay at the hotel brand is pleasant and ambience (e.g. clean rooms and bathrooms, parking space, architectural design, etc.) has put impression on his/her senses.

- Hotel staff competence: The degree to which a guest feels that staff's efficiency, friendliness and professionalism stimulate their senses.

- Hotel website and social media experience: The degree to which a hotel brand's website provides correct information and the presence of hotel brand on social media induces feelings.

- Guest-to-guest experience: The extent to which a guest is affected by the presence of other guests.

We will use these dimensions and their associated scale (Khan and Rahman, 2017) herein.

\subsection{Brand attachment}

The first investigations into brand attachment came from the field of psychology. Bowlby (1977) put forth that basic needs are covered by affective bonds, which begin with the bond between mother and child, and continue with kinship, friendship and romantic relationships (Thomson et al., 2005; Whan Park et al, 2010). A later research by Bowlby (1982), Ugalde et al. (2017) distinguished between the feeling of attachment (with few variations over time) and the behavior of attachment (which occurs sporadically), which mainly differ in terms of the duration of these feelings.

Following these first contributions, scholars analyzed the concept from other perspectives. Thomson et al. (2005) and Whan Park et al. (2010) laid the foundations for this concept in the field of marketing. Both investigations provided different definitions, based on different perspectives, and thus generated different dimensions. However, both of the resulting scales have been commonly accepted and used in subsequent investigations. Consequently, the literature has established that brand attachment encompasses emotional links with brands (Park et al., 2006; Whan Park et al., 2010; Thomson et al., 2005), destinations (Gross and Brown, 2006; Scannell and Gifford, 2010; Tsai, 2012) and even institutions like banks (Levy and Hino, 2016; Taghipourian and Bakhsh, 2016). 
Thomson et al. (2005, p. 78) defined attachment as "an emotion laden target-specific bond between a person and a specific object." They treated this construct as a second-order factor composed of three first-order factors: affection, connection and passion. On the other hand, Whan Park et al. (2010, p. 2) defined it as "the strength of the bond connecting the brand with the self." In this case, there are two critical factors that reflect the conceptual properties of the construct: brand connection (cognitive and emotional connection with the brand) and brand prominence (importance of the cognitive and affective link with the brand, reflected in the frequency with which people remember thoughts and feelings about the brand).

Other authors such as Japutra et al. (2018) or Jiménez and Voss (2014) have proposed alternative measures that seek to concretize and simplify the abstract nature of the construct (Japutra et al., 2018). We decided to use Japutra et al.'s scale for this study, as hotel services are rather intangible, and we thought this scale will be easier for respondents to understand.

\subsection{Hypotheses development}

Khan and Rahman (2017) proposed five dimensions that reflect the hotel brand experience: hotel location, hotel stay and ambience, hotel staff competence, hotel website and social media experience and guest-to-guest experience. However, we have only considered four of them, as we believe that the interaction between clients introduces a component that depends more on external agents (the clients themselves)[1] than on hotel management. Thus, we tested the following hypotheses:

H1a. Hotel location is an antecedent dimension of the brand experience in the hotel.

$H 1 b$. Hotel stay and ambience is an antecedent dimension of the brand experience in the hotel.

H1c. Hotel staff competence is an antecedent dimension of the brand experience in the hotel.

H1d. Hotel website and social media experience is an antecedent dimension of the brand experience in the hotel.

By experiencing the brand in a positive way, consumers create memories and a sense of connection with it, which could favor the creation of emotional bonds (Reihani, 2019). Some research (Bıçakcıŏlu et al., 2016; Garg et al., 2016) has affirmed that the experience promotes the development of emotional ties with the brand. According to Huang (2017), brand love - and by extension, brand attachment (Moussa, 2015; Gómez-Suárez, 2018) have a strong emotional component. Similarly, a study by Japutra et al. (2014) revealed that brand attachment is a consequence of experience. Therefore, experience determines the strength of the link between consumer and brand. These internal and positive responses, generated from a favorable experience, will become positive memories, which result in the creation of links with brands (Huang, 2017; Japutra et al., 2018; Ramirez and Merunka, 2019; Reihani, 2019). We hypothesize that this same process applies to hotel brands. Formally:

H2. The brand experience in the hotel has a direct and positive influence on the hotel brand attachment.

WOM communications are understood as an informal process by which individuals transmit information about an object, brand or service. Because of its informal and noncommercial nature, WOM has high credibility and persuasive power. As such, companies especially those that are service-oriented, such as hotels - are interested in promoting these communications to attract customer traffic (Delgado Ballester and Fernández, 2011). 
SJME

24,2

In this sense, brand experience can favor the generation of WOM. Emotionally charged consumption situations can create psychological tension, which people can relieve through WOM communication (Delgado Ballester and Fernández, 2011). By providing unique and unforgettable experiences, hotels can obtain brand promoters and co-creators of value through positive recommendations (Serra-Cantallops et al., 2018). With this in mind, we propose:

H3. The brand experience in the hotel has a direct and positive influence on WOM recommendations.

Carroll and Ahuvia (2006) defined WOM as "the degree to which the consumer praises the brand to others." Following this definition, Bıçakcioğlu et al. (2016) proposed that consumers who love the brand are more willing to say "good words" to their friends compared to unloved brands. Because some authors like Moussa (2015) consider brand love to be analogous to brand attachment, we propose:

H4. Brand attachment has a direct and positive influence on WOM recommendations.

The hypotheses formulated above assume that both experience and attachment (or its analog, brand love) have a positive effect on WOM. We want to further predict that brand attachment mediates the relationship between experience and positive WOM (Ishikawa, 2013; Biçakcioğlu et al., 2016; Roy et al., 2016; Aro et al., 2018; Hwang and Lee, 2018). Therefore, we propose:

H5. Brand attachment is a mediator of the relationship between brand experience and WOM.

Unlike Khan and Rahman's model (2017), our proposed conceptual model comprises four background factors (location, staff, ambient and Web), as presented in Figure 1.

\section{Methodology}

\subsection{Questionnaire design}

We first presented the participants with a set of introductory questions involving demographic and contextualization issues; these were followed by questions about experience, attachment and recommendations, all measured in a global way. We used a scale

Figure 1.

Theoretical model: antecedents and consequences of brand experience

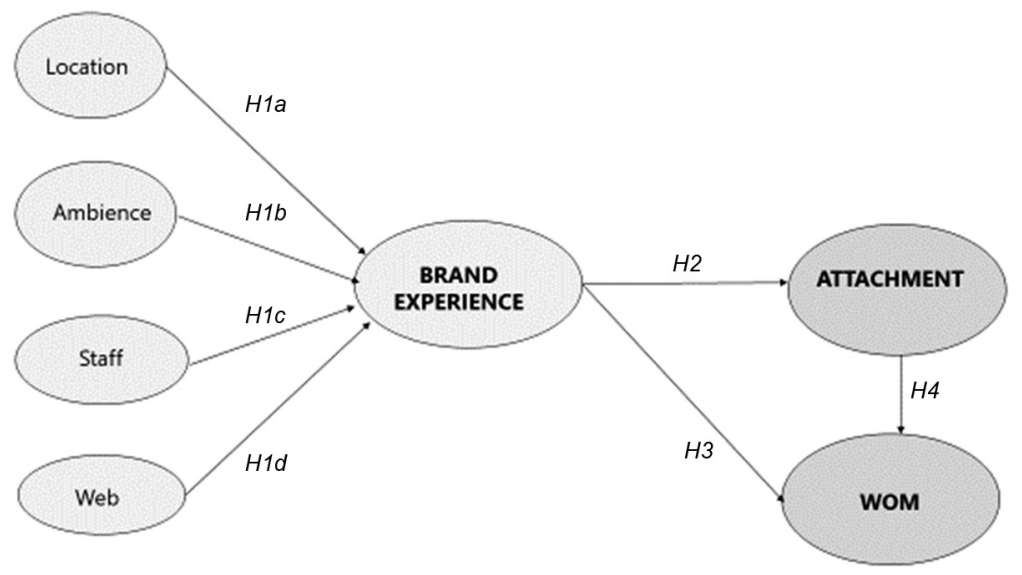


from 0 to 10 for these measurements, in line with expert suggestions that this scale is better suited to global valuations than a 1-7 scale. We used a seven-point Likert scale for the block of questions related to each of the dimensions, as this scale demonstrates optimum reliability (Croasmun and Ostrom, 2011). In this study, we adapted the formula suggested by Preston and Colman (2000):

$$
(\text { Value }-1) /(\text { Number of response categories }-1) \times 100
$$

In our case, we decided to multiply and divide by 10 (instead of 100) to obtain a common score of 10 (Dawes, 2018).

Before we distributed the main questionnaire, we had it reviewed by a committee of four experts (two academic specialists in tourism and two sector executives) who suggested modifications. We then pre-tested the survey with a convenience sample of 24 people. The scales used have been tested in previous research: brand experience (Khan and Rahman, 2017), attachment (Jiménez and Voss, 2014) and WOM recommendations (Khan and Rahman, 2017).

\subsection{Data gathering and sampling}

To obtain the main sample, we used a convenience method. Between April and May 2019, we distributed the questionnaires through Google Forms, which guaranteed the anonymity of the sample. This process produced 426 questionnaires. We eliminated those who did not meet our requirements (failing the control questions, not including description of experience and missing data in key questions), leaving a sample of 416 valid Spanish respondents.

Table 1 presents the demographic characteristics of the sample. The higher response rate among women compared to men generally aligns with the sex breakdown of Spain, according to the INE (Instituto Nacional de Estadística) (Statista, 2019).

\section{Results}

\subsection{Global model adjustment}

The descriptive measures and all items can be found in Appendix. The results of the principal component factor analysis (PCA) with varimax rotation appear in Table 2. We eliminated one of the items related to personnel (STAFF2), as its commonality was less than 0.6. These results coincide with the theoretical proposal, as the four factors (location,

\begin{tabular}{lr}
\hline & $(\%)$ \\
\hline Gender & 61 \\
Female & 39 \\
Male & \\
Age & 37 \\
$<22$ years & 31 \\
$23-43$ years & 32 \\
$>43$ years & 3 \\
Education level & 38 \\
Primary school & 59 \\
Secondary school & \\
University degree & \\
Source: Own elaboration & D
\end{tabular}

\section{experience and} attachment

Brand t 


\begin{tabular}{lllll} 
Description & Staff & Location & Web & Ambience \\
\hline
\end{tabular}

I feel good at this hotel brand because of the staff personnel's attentiveness 0.889

The way in which the staff of this hotel brand serves is admirable $\quad 0.866$

The staff of this hotel brand is helpful and friendly $\quad 0.834$

The location of this hotel brand is convenient that makes me feel

relaxed

The location of this hotel brand stimulates my senses

I find online reviews of this hotel brand informative

The presence of this hotel brand on social media appeals to my

visuals

The website of this hotel brand provides accurate results

This hotel brand has attractive architectural design

The decor of this hotel brand is pleasing

Ambience of this hotel brand is very relaxing to me

$\%$ Explained Variance

$\alpha$

0.873

0.873
0.827

0.811

Table 2.

PCA of brand

Note: ***Significant at 1 per cent

experience

Source: Own elaboration

$\begin{array}{rrrr} & 0.827 & & \\ & 0.811 & & \\ & & 0.900 & \\ & & 0.830 & \\ & & 0.813 & \\ & & & 0.844 \\ & & & 0.781 \\ 21.987 & 20.626 & 19.229 & 0.525 \\ 0.843 & 0.828 & 0.850 & 0.778\end{array}$

environment, personal and Web) are composed of three items that are each related to these possible constructs. The model's goodness-of-fit, as measured by the total variance explained by the four factors (77 per cent), is adequate. In addition, the absence of a single factor implies that there is no common variance bias (Podsakoff et al., 2003). Moreover, we affirmed the reliability of the different scales using Cronbach's $\alpha$ : the values ranged from 0.778 to 0.900 , higher than the critical value of 0.7 (Nunnally, 1979), which indicates the consistency of the proposed scales.

Before testing the hypothesis, we performed a confirmatory factor analysis (CFA) to test the reliability and validity of the scales. With this analysis, we confirmed that the experience scale meets all the psychometric properties related to validity and reliability. This model achieved acceptable goodness-of-fit indicators, especially when considering the large sample $\operatorname{size}\left(\chi^{2} / g .1 .=2,723, \mathrm{GFI}=0.955, \mathrm{CFI}=0.972, \mathrm{TLI}=0.958, \mathrm{RMSA}=0.064\right)$.

Table 3 shows the results of the first-order model. All constructs are reflective. All loads are greater than 0.6, and all items except one are even above 0.7. Additionally, the "critical ratio" (CR), which captures the final configuration of items representing individual values, is high at a significance level of less than 1 per cent. The composite reliability indicators are greater than 0.8, exceeding the cut-off point of 0.7 (Hair, 2006). Meanwhile, the AVE are all greater than 0.6, except for ambience, which still exceeds the critical value of 0.5 (Hair, 2006). Therefore, all scales achieved convergent validity.

To check for discriminant validity, we followed the procedure proposed by Fornell and Larcker (1981), which involves comparing the inter-construct correlation squared with the AVE. If the latter is higher than the former, then we can assume the model possesses discriminant validity. As Table 4 indicates, the AVE is included in the main diagonal and the inter-construct squared correlations are shown in each column below the main diagonal.

To empirically validate the proposed model, we applied an analysis of variancecovariance or structural equation modeling (SEM) using the maximum-likelihood procedure, carried out by the AMOS 24.0 program. 


\begin{tabular}{|c|c|c|c|c|c|c|c|c|c|c|}
\hline \multicolumn{2}{|l|}{ Dimension } & $\mathrm{Li}$ & $R^{2}$ & $1-R^{2}$ & AVE & $\alpha$ & Composite reliability & CR & $p$-value & \multirow{2}{*}{$\begin{array}{r}\text { Brand } \\
\text { experience and } \\
\text { attachment }\end{array}$} \\
\hline UBI1_1 & LOCATION & 0.734 & 0.539 & 0.461 & \multirow[t]{3}{*}{0.637} & 0.828 & \multirow[t]{3}{*}{0.852} & & & \\
\hline UBI2_1 & LOCATION & 0.873 & 0.762 & 0.238 & & & & 15.747 & $* * *$ & \\
\hline UBI3_1 & LOCATION & 0.782 & 0.612 & 0.388 & & & & 15.014 & $* * *$ & \\
\hline WEB1_1 & WEB & 0.782 & 0.612 & 0.388 & \multirow[t]{3}{*}{0.655} & 0.850 & \multirow[t]{3}{*}{0.855} & & & \\
\hline WEB2_1 & WEB & 0.852 & 0.726 & 0.274 & & & & 16.564 & **** & \\
\hline WEB3_1 & WEB & 0.792 & 0.627 & 0.373 & & & & 16.031 & $* * *$ & 239 \\
\hline AMB2_1 & AMBIENCE & 0.688 & 0.473 & 0.527 & \multirow[t]{3}{*}{0.561} & 0.778 & \multirow[t]{3}{*}{0.835} & & & \\
\hline AMB3_1 & AMBIENCE & 0.760 & 0.578 & 0.422 & & & & 13.267 & $* * *$ & \\
\hline AMB4_1 & AMBIENCE & 0.795 & 0.632 & 0.368 & & & & 13.589 & $* * *$ & \\
\hline STAFF $1 \_1$ & STAFF & 0.812 & 0.659 & 0.341 & \multirow[t]{3}{*}{0.731} & 0.843 & \multirow[t]{3}{*}{0.868} & & & \\
\hline STAFF3_1 & STAFF & 0.853 & 0.728 & 0.272 & & & & 19.908 & $* * *$ & \\
\hline STAFF4_1 & STAFF & 0.898 & 0.806 & 0.194 & & & & 20.837 & $* * *$ & 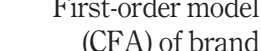 \\
\hline \multicolumn{8}{|c|}{ Source: Own elaboration $* * *$ significant at 1 per cent } & & & \\
\hline
\end{tabular}

\begin{tabular}{|c|c|c|c|c|c|}
\hline & Location & Ambience & Staff & Web & \\
\hline Location & 0.637 & & & & \\
\hline Ambience & 0.402 & 0.561 & & & \\
\hline Staff & 0.199 & 0.456 & 0.731 & & Table 4 . \\
\hline Web & 0.097 & 0.199 & 0.115 & 0.655 & $\begin{array}{l}\text { Discriminant validity } \\
\text { of the first-order }\end{array}$ \\
\hline \multicolumn{5}{|c|}{ Source: Own elaboration } & model \\
\hline
\end{tabular}

As proposed in the theoretical framework, our estimate is based on an antecedent dimensions model. However, we also tested two other possible models (reflective and formative). The model shown in Figure 2, the antecedents model, presented the best goodness of fit and low factor loads. Therefore, the four dimensions related to experience (location, environment, personal and Web) are antecedents of the experience, which is reflected in two global items (importance of experience and memory of it).

The SEM model achieved acceptable goodness-of-fit indicators, thus confirming all the proposed causal relationships. The location is reflected in three items (appealing, convenient and stimulates one's senses); the environment features three items (attractive architectural design, relaxing atmosphere and pleasant decoration), and the staff refers to three items (helpful, admirable attention and feeling good because of the attention). The last dimension of experience refers to the internet, which involves three items (a website offering accurate results, useful online comments and social networks that attract attention).

The results confirmed all hypotheses. We indeed found that the experience encompasses four dimensions: location (0.359), ambience (0.335), staff (0.249) and Web (0.162), which substantiates $H 1 a$ through $H 1 d$. $H 2$ and $H 3$ were also confirmed, as brand experience had a direct, significant and positive standardized effect on attachment (0.656) and WOM (0.657). In turn, attachment is reflected by three items (attached, emotionally connected and affection), while WOM is reflected in three others (relay the experience, recommend the hotel and say positive things about it). The standardized effect of attachment on WOM was low, but also statistically significant (0.173), thus verifying $H 4$. Therefore, with this result, the hypothesis regarding the mediating effect of the attachment between brand experience and the WOM recommendations (H5) is verified. 


\section{SJME}

24,2

\section{0}

Figure 2.

Structural model: antecedents and consequences of brand experience

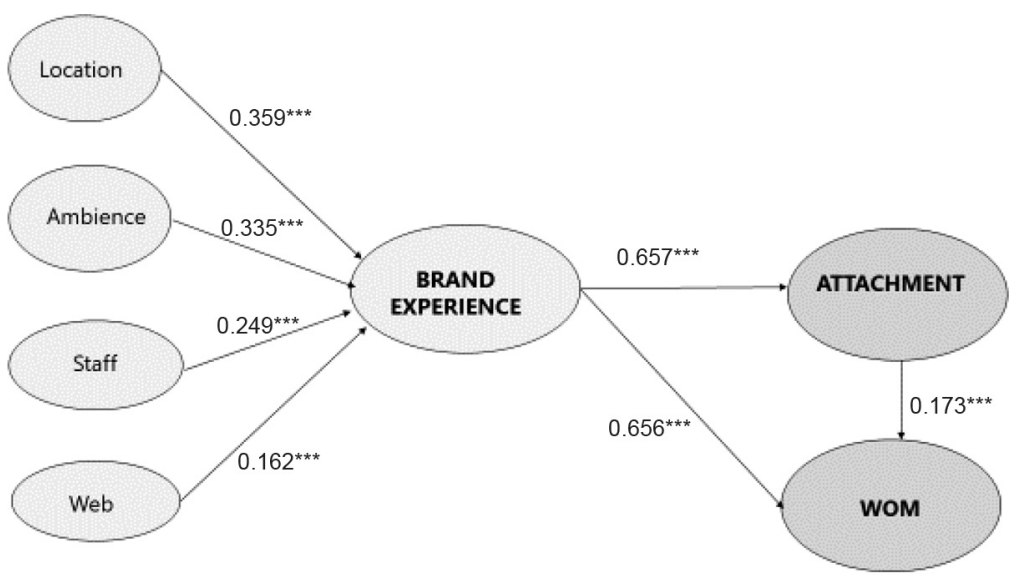

Notes: $\chi^{2} / \mathrm{g} . \mathrm{l}=2.625 ; \mathrm{GFI}=0.902 ; \mathrm{CFI}=0.942 ; \mathrm{TLI}=0.930 ; \mathrm{RMSA}=0.065$;

$* * *$ significant at $1 \%$

Source: Own elaboration

\section{Conclusions and implications}

\subsection{Theoretical implications}

According to the obtained results, the brand experience in the hotel sector is a consequence of four dimensions: location, ambience, staff and Web, in that order of influence. As for the effects on WOM communications, experience has a greater direct impact than attachment.

Our research empirically substantiates what Khan and Rahman (2017) already advanced: The brand experience in a hotel differs from the brand experience that arises from more tangible goods or experiences. While both involve a subjective response to external stimuli, Brakus et al.'s (2009) definition is more abstract about intangible services; as a result, it is weakly applicable to the tourism market. The items that reflect the four dimensions of Brakus et al.'s (2009) model - sensory, cognitive, affective and behavioral - are difficult to understand in a study that depends on participants' memory rather than a previous experiment or particular stimuli exposure. For our more general study, the four dimensions of the Khan and Rahman scale (2017) - location, staff, atmosphere and Web - refer to more observable and easy-to-remember issues. That said, our proposed model and obtained results indicate that these dimensions are not a reflection of experience, but rather are shaped as antecedent constructs.

Additionally, we followed Khan and Rahman's (2017, p. 284) research proposal to validate and extend their scale in contexts other than luxury hotel brands. Specifically, our study verified this scale's validity for hotels of any category, as these are the spontaneously chosen by the respondents. The obtained results also confirm that experience has a positive and direct impact on WOM, which aligns with previous research about this relationship (Delgado Ballester and Fernández, 2011; Khan and Fatma, 2017; Khan and Rahman, 2017; Serra-Cantallops et al., 2018).

Theoretically, the study addresses and empirically validates the mediating role of brand attachment in the relationship between brand experience and WOM. This is a novelty, as previous research had only shown that attachment is a consequence of experience (Ishikawa, 2013; Huang, 2017; Ramirez and Merunka, 2019; Reihani, 2019), or that affection 
toward brands or tourist destinations increases WOM recommendations (Carroll and Ahuvia, 2006; Biçakcioğlu et al., 2016). However, no study has yet established brand attachment's mediating role, at least in the hotel context.

In short, the main contribution of our work is confirming that consumers are more likely to make WOM recommendations about a hotel when they develop emotional ties with said hotel through an experience that they consider intense and can easily recall.

\subsection{Practical implications}

Hotel managers should focus on providing unique experiences by strategically aligning their business with the four dimensions that comprise such experiences. These dimensions play an important role for both the development of emotional bonds and the likelihood of spurring WOM recommendations.

Regarding the location, for example, hotels can reach agreements with nearby restaurants or shops to offer promotions to guests. The hotels can then garner goodwill by informing customers about nearby accommodations. In cases where hotels are surrounded by nature or beaches, they can promote tours around the environment or even include photographs of the surroundings. Media could be shown on screens in common areas to raise awareness among guests.

It is worth highlighting the importance of hotel staff in the brand experience. In many cases, the correct management of an incident can transform a bad experience into a very positive one. Therefore, firms should incorporate coaching processes into their staff trainings in order to cover issues like emotional intelligence or managing complicated situations.

The results also underscore the need to improve the online experience. The average values obtained in the Web-related items were lower than the rest. According to Brakus et al. (2009, p. 52), consumers' brand experience encompasses their search, purchase, receipt and consumption activities. Therefore, websites should be designed around providing clear and precise information, as well as a good shopping experience. In addition, hotels need to better incorporate social networks into their strategies in attract new customers and increase WOM recommendations through them (eWOM). Tourists often take photos during their trips and upload them to their social networks so as to exhibit their experiences, feelings and identity (Luna-Cortés, 2017). For instance, many younger consumers are migrating from Facebook to Instagram (Marcelino Mercedes, 2015) because of the latter's stronger ability to capture and share moments of everyday life (Belanche et al., 2019). Therefore, hotels must work to integrate "instagrammable everyday moments" into the design of their environments, thereby encouraging customers to capture and share these experiences. In this way, hotels can reach a wider audience in a less intrusive way, as these efforts are not ostensibly about advertising and are carried out by people whom users voluntarily follow.

\subsection{Limitations and future research}

The main limitation of this study is our choice to use a convenience sample, which is why some caution should be taken when generalizing the results. Our results could have been impacted by potential biases related to the three classification variables (sex, age and studies). Future studies on this moderating effect should control for these variables, as well as stratify the sample before performing the fieldwork. For instance, it would interesting to control for whether the respondent had previous experience with the hotel.

Meanwhile, our results open two major areas of research. First, the same model can be applied in other geographic markets. A cross-cultural investigation would provide stronger empirical evidence about the experience scale, as well as the nature of the relationships 
between the main dimensions. Second, scholars could adapt the model to other services (e.g. distribution, financial markets, the collaborative economy, etc.) where the experience is largely intangible, and regular brand experience models cannot be applied directly. These efforts might lead to more specific scales, based on tangible dimensions, that clarify the relationship between experience, attachment and recommendations.

Finally, this study explored the effect of experience on WOM recommendations, but did not consider its impact on online recommendations. Thus, future research could prove the relationship between positive experience and online recommendations. As mentioned above, tourists take photos during their stay to share these memories on their social networks, so testing this relationship would be especially valuable.

\section{Note}

1. However, this fifth dimension was included in the pre-test. The results of the exploratory analysis and the respondents' comments led us to exclude it from the final questionnaire.

\section{References}

Andreini, D., Pedeliento, G., Zarantonello, L. and Soleiro, C. (2018), “A renaissance of brand experience: advancing the concept through a multi-perspective analysis", Journal of Business Research, Vol. 91, pp. 123-133.

Aro, K., Suomi, K. and Saraniemi, S. (2018), "Antecedents and consequences of destination brand lovea case study from Finnish Lapland", Tourism Management, Vol. 67, pp. 66-78.

Beckman, E., Kumar, A. and Kim, Y.K. (2013), “The impact of brand experience on downtown success”, Journal of Travel Research, Vol. 52 No. 5, pp. 646-658.

Beerli, A. and Martín, J.D. (2004), "Factors influencing destination image", Annals of Tourism Research, Vol. 31 No. 3, pp. 657-681.

Belanche, D., Cenjor, I. and Pérez-Rueda, A. (2019), "Instagram stories versus Facebook wall: an advertising effectiveness analysis", Spanish Journal of Marketing - ESIC, Vol. 23 No. 1, pp. 69-94.

Bıçakcıŏlu, N., İpek, İ. and Bayraktaroğlu, G. (2016), "Antecedents and outcomes of brand love: the mediating role of brand loyalty", Journal of Marketing Communications, Vol. 24 No. 8, pp. 863-877.

Bowlby, J. (1977), "The making and breaking of affectional bonds", British Journal of Psychiatry, Vol. 130 No. 5, pp. 421-431.

Bowlby, J. (1982), “Attachment and loss: retrospect and prospect”, American Journal of Orthopsychiatry, Vol. 52 No. 4, pp. 664-678.

Brakus, J.J., Schmitt, B.H. and Zarantonello, L. (2009), "Brand experience: what is it? How is it measured? Does it affect loyalty?”, Journal of Marketing, Vol. 73 No. 3, pp. 52-68.

Carroll, B.A. and Ahuvia, A.C. (2006), "Some antecedents and outcomes of brand love", Marketing Letters, Vol. 17 No. 2, pp. 79-89.

Croasmun, J.T. and Ostrom, L. (2011), "Using Likert-type scales in the social sciences”, Journal of Adult Education, Vol. 40 No. 1, pp. 19-22.

Dawes, J. (2018), "Do data characteristics change according to the number of scale points used? An experiment using 5-Point, 7-Point and 10-Point scales", International Journal of Market Research, Vol. 50 No. 1, pp. 61-104.

Del Barrio García, S., Moreno, L.L. and Jamilena, D.M.F. (2012), "El tipo de incentivo como determinante en el atractivo de la promoción de venta en turismo rural. Efecto moderador del sexo, la edad y la experiencia”, Revista Española de Investigación de Marketing Esic, Vol. 16 No. 2, pp. 103-126. 
Delgado Ballester, M.E. and Fernández, E. (2011), "Marcas de experiencia: marcando la diferencial”, Estudios Gerenciales, Vol. 27 No. 121, pp. 59-77.

Fornell, C. and Larcker, D. (1981), "Evaluating structural equation models with unobservable variables and measurement", Journal of Marketing Research, Vol. 18 No. 1, pp. 39-50.

García, J., Galindo, A. and Suárez, R. (2018), "The effect of online and offline experiential marketing on brand equity in the hotel sector", Spanish Journal of Marketing - ESIC, Vol. 22 No. 1, pp. 22-41.

Garg, R., Mukherjee, J., Biswas, S. and Kataria, A. (2016), "An investigation into the concept of brand love and its proximal and distal covariates", Journal of Relationship Marketing, Vol. 15 No. 3, pp. 135-153.

Gilmore, J.H. and Pine, B.J. (2002a), "Differentiating hospitality operations via experiences: why selling services is not enough", The Cornell Hotel and Restaurant Administration Quarterly, Vol. 43 No. 3, pp. 87-96.

Gilmore, J.H. and Pine, B.J. (2002b), "Customer experience places: the new offering frontier", Strategy \& Leadership, Vol. 30 No. 4, pp. 4-11.

Gómez-Suárez, M. (2018), "Examining customer-brand relationships: a critical approach to empirical models on brand attachment, love, and engagement", Administrative Sciences, Vol. 9 No. 1, pp. 1-19.

Gross, M.J. and Brown, G. (2006), "Tourism experiences in a lifestyle destination setting: the roles of involvement and place attachment", Journal of Business Research, Vol. 59 No. 6, pp. 696-700.

Hair, J.F. Jr, (2006), 'Multivariate Data Analysis, 7th ed., Pearson Education, NJ.

Huang, C.C. (2017), "The impacts of brand experiences on brand loyalty: mediators of brand love and trust", Management Decision, Vol. 55 No. 5, pp. 915-934.

Hwang, J. and Lee, K.W. (2018), “The antecedents and consequences of golf tournament spectators' memorable brand experiences", Journal of Destination Marketing and Management, Vol. 9, pp. 1-11.

Ishikawa, K. (2013), "Brand dynamics: the effects of brand personality and brand experience on emotional brand attachment", Keio University, 1994 M. A, Rikkyo University, 1997 A Dissertation Submitted in Partial Fulfillment of the Requirements fo', tesis doctoral.

Jain, R., Aagja, J. and Bagdare, S. (2017), "Customer experience - a review and research agenda", Journal of Service Theory and Practice, Vol. 27 No. 3, pp. 642-662.

Japutra, A., Ekinci, Y. and Simkin, L. (2014), "Exploring brand attachment, its determinants and outcomes", Journal of Strategic Marketing, Vol. 22 No. 7, pp. 616-630.

Japutra, A., Ekinci, Y. and Simkin, L. (2018), "Tie the knot: building stronger consumers' attachment toward a Brand", Journal of Strategic Marketing, Vol. 26 No. 3, pp. 223-240.

Jiménez, F. and Voss, K. (2014), "An alternative approach to the measurement of emotional attachment", Psychology and Marketing, Vol. 31 No. 5, pp. 360-370.

Kang, A. (2015), "Brand love - moving beyond loyalty an empirical investigation of perceived brand love of Indian consumer", Arab Economic and Business Journal, Vol. 10 No. 2, pp. 90-101.

Khan, I. and Fatma, M. (2017), "Antecedents and outcomes of brand experience: an empirical study", Journal of Brand Management, Vol. 24 No. 5, pp. 439-452.

Khan, I. and Rahman, Z. (2015), "A review and future directions of brand experience research", International Strategic Management Review, Vol. 3 Nos 1/2, pp. 1-14.

Khan, I. and Rahman, Z. (2017), "Development of a scale to measure hotel brand experiences", International Journal of Contemporary Hospitality Management, Vol. 29 No. 1, pp. 268-287.

Levy, S. and Hino, H. (2016), "Emotional brand attachment: a factor in customer-bank relationships", International Journal of Bank Marketing, Vol. 34 No. 2, pp. 136-150.

Luna-Cortés, G. (2017), "The influence of symbolic consumption on experience value and the use of virtual social networks", Spanish Journal of Marketing - ESIC, Vol. 21 No. 1, pp. 39-51. 
Marcelino Mercedes, G.V. (2015), "Migración de los jóvenes españoles en redes sociales, de tuenti a facebook y de facebook a instagram. La segunda migración”, Revista Icono14 Revista Científica de Comunicación y Tecnologías Emergentes, Vol. 13 No. 2, pp. 48-72.

Moussa, S. (2015), "I may be a twin but I'm one of a kind: are brand attachment and brand love different names for the same construct?", Qualitative Market Research: An International Journal, Vol. 18 No. 1, pp. 69-85.

Nunnally, J.C. (1979), "Psychometric theory”, 2nd ed., Applied Psychological Measurement.

Park, C.W., MacInnis, D.J. and Priester, J. (2006), "Brand attachment: brand attachment: constructs, consequences", Foundations and Trends in Marketing, Vol. 1 No. 3, pp. 1-31.

Pine, B.J. and Gilmore, J.H. (1998), "Welcome to the experience economy", Harvard Business Review, Vol. 76 No. 4, pp. 97-105.

Podsakoff, P.M., MacKenzie, S.B. and Podsakoff, N.P. (2003), "A critical review of the literature and recommended remedies”, Journal of Applied Psychology, Vol. 88 No. 5, pp. 803-879.

Preston, C.C. and Colman, A.M. (2000), "Optimal number of response categories in rating scales: reliability, validity, discriminating power, and respondent preferences”, Acta Psychologica, Vol. 104 No. 1, pp. 1-15.

Pullman, M. and Gross, M. (2004), "Ability of experience design elements to elicit emotions and loyalty behaviors”, Decision Sciences, Vol. 35 No. 3, pp. 551-578.

Ramirez, R. and Merunka, D. (2019), "Brand experience effects on brand attachment: the role of brand trust, age, and income”, European Business Review, Vol. 31 No. 5, pp. 610-645.

Reihani, N. (2019), "Brand attachment in consumer-brand relationship", Journal of System Management, Vol. 2, pp. 41-60.

Roy, P., Khandeparkar, K. and Motiani, M. (2016), “A lovable personality: the effect of brand personality on brand love”, Journal of brand Management, Vol. 23 No. 5, pp. 97-113.

Scannell, L. and Gifford, R. (2010), "Defining place attachment: a tripartite organizing framework", Journal of Environmental Psychology, Vol. 30 No. 1, pp. 1-10.

Schmitt, B. (1999), "Experiential marketing”, Journal of Marketing Management, Vol. 15 Nos 1/3, pp. 53-67.

Serra-Cantallops, A., Ramon-Cardona, J. and Salvi, F. (2018), "The impact of positive emotional experiences on eWOM generation and loyalty", Spanish Journal of Marketing - ESIC, Vol. 22 No. 2, pp. 142-162.

Statista (2019), Disponible en: https://es.statista.com/estadisticas/472331/poblacion-de-espana-porgenero/ (accessed 9 January 2020).

Sukhu, A., Choi, H., Bujisic, M. and Bilgihan, A. (2018), "Satisfaction and positive emotions: a comparison of the influence of hotel guests' beliefs and attitudes on their satisfaction and emotions”, International Journal of Hospitality Management, Vol. 77, pp. 51-63.

Taghipourian, M.J. and Bakhsh, M.M. (2016), "Brand attachment on service loyalty in banking sector", International Journal of Marketing Studies, Vol. 6 No. 5, pp. 146-156.

Thomson, M., MacInnis, D.J. and Park, C.W. (2005), "The ties that bind: measuring the strength of consumers' emotional attachments to brands", Journal of Consumer Psychology, Vol. 15 No. 1, pp. 77-91.

Tsai, S. (2012), “The formation of the tourist's loyalty how does it affect price discounts?", International Journal of Tourism Research, Vol. 14 No. 2, pp. 139-152.

Ugalde Sánchez, C.E., Vila López, N.M. and Küster Boluda, I. (2017), “Antecedentes y efectos del apego a la marca: Papel moderador del posicionamiento de marca por atributo preeminente y de la implicación en la categoría del producto", tesis doctoral.

Walls, A.R. (2013), "A cross-sectional examination of hotel consumer experience and relative effects on consumer values”, International Journal of Hospitality Management, Vol. 32 No. 1, pp. 179-192. 
Whan Park, C., Priester, J., Eisingerich, A.B. and Iacobucci, D. (2010), "Brand attachment and brand attitude strength: conceptual and empirical differentiation of two critical brand equity drivers", Journal of Marketing, Vol. 74 No. 6, pp. 1-17.

\section{Further reading}

Huang, Y.-T. and Jian, S.-P. (2015), "From customer satisfaction to brand loyalty: a mediation model of brand trust and brand love", Marketing Review (Xing Xiao Ping Lun), Vol. 12 No. 2, pp. 161-188.

Ugalde, C., Vila López, N., Küster Boluda, I. and Mora, E. (2019), "Notoriedad y credibilidad de marca como antecedentes a su apego", Obra Digital, Vol. 16, pp. 63-76. 


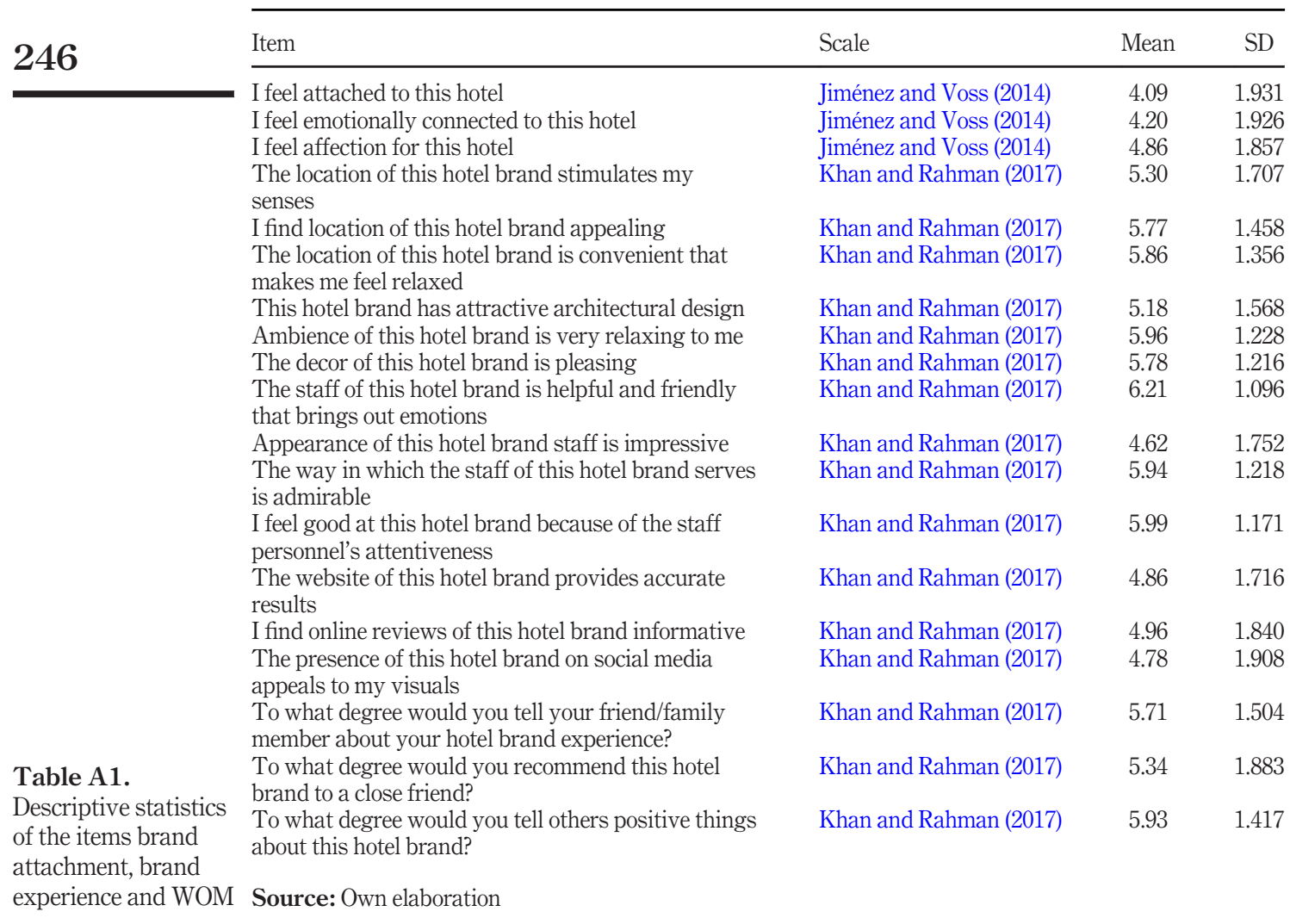

\section{Corresponding author}

Mónica Veloso can be contacted at: monica.veloso@uam.es

For instructions on how to order reprints of this article, please visit our website: 